\title{
High-precision zircon petrochronology of Paleogene intraplate calderas, Central Oregon, USA: contrasting the formation of hot and cool rhyolitic magmas
}

\author{
DYLAN COLON ${ }^{1}$, PROF. URS SCHALTEGGER, PHD $^{2}$, \\ ANGELA SELIGMAN $^{3}$ AND ILYA N. BINDEMAN ${ }^{4}$ \\ ${ }^{1}$ Université de Genève \\ ${ }^{2}$ University of Geneva \\ ${ }^{3}$ North Dakota Department of Environmental Quality \\ ${ }^{4}$ University of Oregon \\ Presenting Author: dylan.colon@unige.ch
}

The $\sim 40$ Ma Wildcat Mountain Caldera and the $\sim 30$ Ma Crooked River Caldera are two adjacent large-volume silicic eruptive systems in an intraplate environment between $60 \mathrm{~km}$ and $80 \mathrm{~km}$ east of the Cascades subduction arc in Oregon in the northwest USA. The older Wildcat Mountain system is calcalkaline and appears to be fairly typical of other similar-aged "ignimbrite flareup" tuffs of the western interior United States. The Crooked River volcanic field is a much larger tholeiitic system, dominated by the $\sim 500 \mathrm{~km}^{3}$ Tuff of Smith Rock along with several other smaller high-silica rhyolite tuffs and lavas. Most strikingly, and unlike at Wildcat Mountain, many of the large-volume rhyolites at Crooked River have distinctly low $\delta^{18} \mathrm{O}$ values in their phenocrysts, similar to many rhyolites found in the Yellowstone hot spot track to the east, suggesting that the magmas were at least partially formed by melting of shallow, hydrothermally altered rocks.

We present new high-precision CA-ID-TIMS U-Pb ages from zircon from rhyolitic tuffs and lavas from Wildcat Mountain and Crooked River to contrast the development of eruptible magmas in these very different magmatic systems. We are pairing these dates with new trace element in zircon measurements made via laser ablation ICP-MS, and with $\mathrm{O}$ and Hf isotopic data, which were obtained from the same crystals. We confirm via the Ti-inzircon thermometer that Crooked River magmas were significantly hotter than Wildcat Mountain magmas and show that the Crooked River zircon were also depleted in trace elements including heavy REEs and had much smaller negative $\mathrm{Eu}$ anomalies. As they were processed through essentially the same crust, this suggests that the differences between these systems arise in the mantle. We suggest that a greater magmatic flux from the mantle, possibly involving the Yellowstone mantle plume, allowed the hotter magmas of the Crooked River system to melt shallow crust prior to eruption unlike the cooler and more crystal-rich Wildcat Mountain magmas. 